\title{
A conceptual framework for socializing the Iranian health system
}

Ali-Asghar Farshad, ${ }^{1}$ Roksana Mirkazemi, ${ }^{2}$ Narges Rostamigooran, ${ }^{3}$ Seyyed Mohammad Hadi Ayazi ${ }^{4}$ and Masoud Motalebi ${ }^{1}$

${ }^{1}$ Occupational Health Research Center, Iran University of Medical Sciences, Tehran, Islamic Republic of Iran. ${ }^{2}$ Farzanegan Nik Andish Institute for the Development of Knowledge and Technology, Tehran, Islamic Republic of Iran. ${ }^{3 S e c r e t a r i a t ~ o f ~ t h e ~ S u p r e m e ~ C o u n c i l ~ o f ~ H e a l t h ~ a n d ~ F o o d ~ S e c u r i t y, ~ T e h r a n, ~}$ Islamic Republic of Iran. ${ }^{4}$ Social Deputy, Ministry of Health and Medical Education, Tehran, Islamic Republic of Iran. (Correspondence to: Roksana Mirkazemi: r.mirkazemi@gmail.com).

\begin{abstract}
Background: Socializing the health system is a new approach to participatory governance that aims to promote community health and enhance sustainable health equity in the community. This approach is a part of health system reform in the Islamic Republic of Iran.
\end{abstract}

Aims: This study aimed to develop a conceptual framework for socializing the health system in the Islamic Republic of Iran as a theoretical basis for this reform.

Methods: Data were gathered through a review of the literature, in-depth interviews, focus group discussions, and panel discussions. Participants were experts in the field of health systems within the health ministry and medical universities. Content analysis was used to analyse the data and identify core values, principles, and approaches for socializing the health system.

Results: The core values identified included human dignity, equity, ethics, and trust. The principles were participation, empowerment, human rights, and responsiveness. The approaches identified were good governance, a health-oriented focus, capacity-building, a process-oriented method, and improvement in the social determinants of health. A strong political will was considered essential for socializing the health system.

Conclusions: The conceptual framework outlines requirements for socializing the Iranian health system. As this is a new approach in health system governance, however, it needs to be refined and redefined through implementation and evaluation.

Key words: participatory governance, public health, health systems, health equity, Iran.

Citation: Farshad A-A; Mirkazemi R; Rostamigooran N; Ayazi SMH; Motalebi M. A conceptual framework for socializing the Iranian health system. East Mediterr Health J. 2021;27(6):629-637. https://doi.org/10.26719/emhj.21.014

Received: 12/05/19; accepted: 03/02/20

Copyright (c) World Health Organization (WHO) 2021. Open Access. Some rights reserved. This work is available under the CC BY-NC-SA 3.o IGO license (https://creativecommons.org/licenses/by-nc-sa/3.0/igo).

\section{Introduction}

"Complexity defines health" in the age of globalization (1). Around the world, health systems are trying to cope with this complexity to ensure a balance between improving health and promoting equity by adopting different policies and actions. Health in all policies $(2,3)$, all for health (4) and good governance in health systems (5) are examples of these different initiatives. Socializing the health system, a new approach to participatory governance in the health system in the Islamic Republic of Iran, is an initiative to address this complexity and to fulfill the duties of the health system across the country. Socializing the health system refers to a series of systematic actions to promote community health and enhance health equity in the community by identifying all the existing capacities and resources for health preservation and promotion, empowering the human resources, and organizing these resources to improve health system management.

The health care system in the Islamic Republic of Iran has achieved much in the past 5 decades (6-8). However, more recently, certain issues - such as the epidemiological transition towards lifestyle diseases
$(9,10)$, shifts in the demographic pattern (11) and achieving health equity (6) - have concerned policy-makers in the health system. In addition to these issues, other factors have motivated health system policy-makers to plan a new approach in governance of the health system. These factors include: corruption and unethical or irresponsible behaviour of health service providers around the country (12-14), a better understanding of the importance of life settings and neighbourhood climate to the health of individuals $(15,16)$, gravitation towards people power among the general population and a better understanding of the important role of social determinants of health on public health (17). This new approach is a paradigm shift in the health system of the Islamic Republic of Iran towards socializing the health system and is a part of the health system reform in the country. Socializing the health system can be considered either as a radical idea in the governance of the health system or as an essential need for health improvement in the current situation of the Islamic Republic of Iran. An Iranian study on the meaning of socialization of health to Iranian policy-makers emphasized the gaps in agreement among different stakeholders about the definition and 
conceptual framework of socializing the health system in the country (18).

The first step to socializing the health system is developing a conceptual framework. At the request of the Social Deputy of the Ministry of Health in the Islamic Republic of Iran, this study, therefore aimed to develop a conceptual framework for socializing the health system to create a unity of vision among all stakeholders. This conceptual framework defines the theoretical aspects, values and principles, and approaches of this process.

\section{Methods}

\section{Study design}

To conceptualize socializing the health system in the Islamic Republic of Iran, we used a mixed-method that integrated an extensive review of the literature and qualitative methods. This method allowed us to gain a deeper understanding of the perspective of and dialogue between key informants and policy-makers on this issue at the national level, as well as the international context and evidence. As we collected ideas and developed a consensus on socializing the health system, we used a content analysis technique to analyse the data. This study follows COREQ (consolidated criteria for reporting qualitative research) guidelines (19).

\section{Research team}

The research team included high-ranking personnel of the Ministry of Health and Medical Education including the Social Deputy of the ministry, the Secretariat of the Supreme Council of Health and Food Security and experts in the Supreme Council of Health and Food Security, as well as a research consultant. The team, together with two note-takers, undertook in-depth interviews, focus group discussions, and panel discussions.

\section{Participants and data collection}

All the participants in this study were key informants and experts in the field of health care systems who held high positions in the Ministry of Health and Medical Education or medical universities and were very familiar with the concept and importance of socializing health. All participants were approached through a formal letter from the Secretariat of Supreme Council of Health and Food Security. The in-depth interviews were done at the Ministry of Health and Medical Education or at the personal offices of participants who were retired or working outside the ministry. The focus group and panel discussions were done at the Ministry of Health and Medical Education. We used purposive sampling to select all participants for the interviews and discussions.

\section{In-depth interviews}

To have a clear definition of the meaning of socializing the health system, in-depth interviews were held with six experts (all male): the health deputy, social deputy, and food and drug deputy of the Ministry of Health and Medical Education and key informants who had worked for a long time at the ministerial level. Each interview took 60-90 minutes. Different aspects of socializing of the health system were discussed in the interviews including the definition and theoretical issues, and the advantages and possibilities of socializing the health system. The interviews were audio-recorded, transcribed, and evaluated by content analysis.

\section{Focus groups discussions}

After gathering the basic information on the definition and conceptual aspects of socializing the health system through review of the literature, two focus groups discussions were conducted with 16 participants (two women and 14 men) including experts from the Ministry of Health and Medical Education, the Iranian Academy of Medical Sciences, members of the Secretariat of Supreme Council for Health and Food Security and the heads of the three medical universities in Tehran. The purpose of these focus groups discussions was to discuss the finding of the above-mentioned in-depth interviews and further expand and explore the definition and theoretical and practical aspects of socializing the health system. The focus groups discussions were conducted by one facilitator, who was a member of the Secretariat of Supreme Council for Health and Food Security, and one note taker. The discussions lasted 150-180 minutes. The discussions were audio-recorded, transcribed, and evaluated by content analysis.

\section{Literature review}

An extensive review of relevant national and international literature was undertaken using the following keywords: socializing, governance, participat*, health care system, service, community-based, social determinant of health, ethics, values, the conceptual framework", participatory medicine, medical education, coherence, social engagement, community involvement, cohesion, and integrity. Grey literature and non-peer-reviewed papers were not included. We searched Google Scholar, PubMed, and Scopus databases for articles published from 1998 to 2018. In addition, the serial document search method was used to find relevant documents. The search yielded 1660 documents. We reviewed the title of the documents and in some cases the abstract to select the eligible documents. We included all documents that addressed any concept or approach relevant to people participation in health system governance. More than 150 documents were included and studied carefully and relevant concepts, values, principles, and approaches to socializing the health system were recorded.

\section{Drafting a conceptual framework and panel discussions}

Based on the results of the literature review, in-depth interviews and focus group discussions, the first draft of the conceptual framework was developed by the research consultant.

This first draft of the conceptual framework on socializing health was shared and modified in the four panel discussions with 52 experts (eight women and 
44 men) including: the Minister of Health and Medical Education; different deputies of the ministry and representative of different governmental organizations (Ministry of Agriculture, State Welfare Organization, Ministry of Youth Affairs and Sports, Ministry of Roads and Urban Development, Ministry of Industry, Mine and Trade, Ministry of Cooperatives, Labour and Social Welfare, Ministry of Education); social deputies of 23 of 28 universities of medical education around the country; and representative of non-governmental organizations and civil societies. The reason for selecting many experts for the panel discussion from different fields and organizations was to have the opinion and participation of representatives of different stakeholders and to create a unified vision among the main stakeholders.

The draft conceptual framework was sent by email to the panel members before the panel sessions and was presented in the panel discussions. The experts could send their views and comments by email, and also give their views in the panel discussions. The panel discussions lasted 180-240 minutes.

The comments and views of the panel members were analysed using content analysis and the draft of the conceptual framework was modified based on the discussions in five revisions. The framework was finalized after approval by the panel members and all the experts involved.

\section{Data analysis}

We undertook a content analysis of the in-depth interviews and focus group discussions. Two experts manually coded the data; in case of discrepancy, a third expert reviewed the data and made the final decision. Themes (core values, principles and approaches) were identified in advance based on defining the core values, principles and approaches.

We undertook a narrative analysis of the results of panel discussions, using a deductive approach. The results were used to modify and revise the first draft of the conceptual framework.

\section{Ethical considerations}

We explained the purpose of the study to the participants and assured them of the confidentiality of their contribution. Verbal consent was obtained from all the participants.

\section{Results}

The first draft of the conceptual framework provided the definition for socializing the health system, identified the main players and described the core values, principles and approaches of socializing the health system. This draft was modified and unanimously agreed upon by the participants in the focus group discussions and panel discussions.

\section{Definition of socializing the health system}

Based on the consensus of the experts in the field, socializing of the health system was defined as, "A series of systematic actions to promote community health and enhance sustainable health equity in the community by identifying all the existing capacities and resources (within and outside the health sector), empowering them and organizing them in order to participate in the health system management (policy-making, implementation and monitoring)." Four groups need to be involved to promote health and sustainable health equity: non-health sector players through intersectoral collaboration; the private sector through public-private partnership; nongovernmental organizations, associations, civil societies, volunteers and charities which represent the organized and formal form of people's participation; and local communities.

The systematic actions could refer to any endeavours or measures by health system governance to create opportunities for meaningful participation of people and communities, such as: involving and engaging the four main players in health affairs; nurturing and empowering them; providing the required data and information such as health status and health needs; creating a platform for collaboration; providing financial and technological support; and creating a sense of ownership and responsibility for the health of self and others. Through this meaningful participation, the four main groups will use their resources and capacities to preserve and promote health, generate knowledge relevant to their own health needs and demands, and use this knowledge to preserve and promote their health. Figure 1 shows the model of this relationship and participation among the different player groups in socializing the health system.

\section{Core values}

Participation was identified as the explicit value for socializing the health system, which is linked to implicit values such as human dignity, equity and social justice, ethics and trust. Human dignity is a universal core value that lays the foundation for the participation of people in decision-making related to their own affairs, and for a system to value the health and well-being of each individual. Equity is another core value identified for socializing the health system. Equity is not just the equitable distribution of services or determinants of health, but more broadly the ability of people to access knowledge, critically analyse the available knowledge and information, make a sound decision for their own health and safety and act upon their decisions. The participants expressed the importance of health equity and justice as for example: "everyone has a right to be healthy", "people have equal right to access health services", "health must be for all", and "everyone should be covered by good-quality health services".

Trust is necessary for participation; without trust, people will not participate and socializing the health system would face failure. In the context of socializing the health system, ethics has a broader spectrum than 
Figure 1 Conceptual model of the relationship between health governance and other main players in socializing the health system in the Islamic Republic of Iran

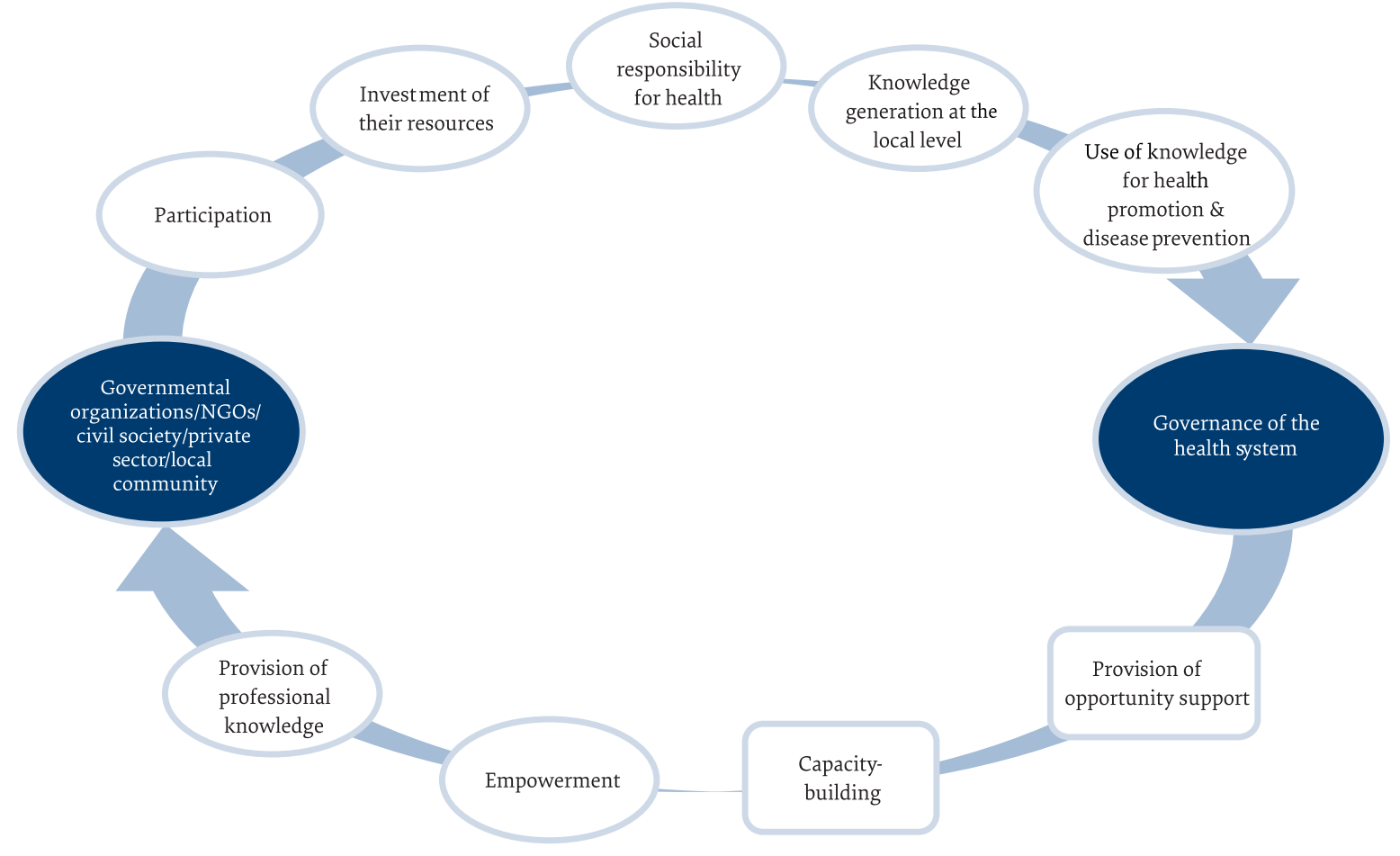

just professional ethics and integrity. It also covers the responsibility of the health system to promote social justice and equity, and reduce discrimination, vulnerability and marginalization in the society. Furthermore, socializing the health system is an ethical approach itself. The participants indicated the importance of ethics through statements such as: "ethics must be strengthened in medical education", and "the values of the Patient Rights Charter must be considered in all health services."

Materialism (money-centred focus) in today's society, in its hidden or apparent forms, governs many health-related affairs, from research to priority setting (prioritizing highly specialized interventions over simple useful interventions), to budget allocation (for the benefit of the minority rich strata of society), to policy-making (that preserves the control of a minority). Therefore, moving towards socializing of health is an ethical approach that enables people to prevent policies and actions that increase health inequity and limit healthy choices. In addition, ethics should be the driving force of all decision-making to ensure maximum good for the maximum number of people.

\section{Principles}

Participation is not only a core value, but also the main principle of socializing the health system. One of the participants indicated that "the people must participate in the production of health services, delivery of health services and overall for all their own health services". Participation of people can give them control over their health and whatever affects their health. However, a higher lev- el of participation is necessary for socializing the health system that is participation in the generation, application and dissemination of knowledge. Participants made reference to this participation in the interviews; for example: "people must participate in policy-making", "people must participate in health system implementation", "people must participate in monitoring the health system", "people must participate in health research" and "everyone should follow the issues of health partnership from his/ her own perspective." The hierarchy between those who generate knowledge and those who are the consumers of knowledge and technology (the people) could result in increasing gaps in power and control. When people actively participate in the generation of knowledge relevant to their own needs and demands, they are more willing and able to apply this knowledge to their own lives. In addition, when people disseminate knowledge, the knowledge would be shared more widely and effectively among different groups of people and communities who are first-hand users of this knowledge. Therefore, the health system in its move towards socializing of health should enhance people's participation in the generation, application and dissemination of knowledge.

Participatory approaches mean that all stakeholders and main players should participate actively in policymaking, implementation, monitoring and evaluation of all health-related affairs that influence them or are influenced by them.

The principle of empowerment is at the heart of participation. Capacity-building and empowerment play a crucial role in enabling participation. Indeed, participation and empowerment are two sides of the 
same coin. When people are empowered, to the level of their capacity, they can take responsibility and participate in their own and their society's health affairs; and when people have the opportunity to participate in healthrelated affairs, they become empowered and capable of greater and more effective participation.

Empowerment should not just be limited to the people and communities; empowerment within the health sector is also necessary to be able to deal with the different levels of complexity of participatory planning, implementation, monitoring and service provision. Empowerment should also include different governmental and non-governmental organizations and civil society. Empowerment is a vital element of health equity.

Socializing the health system requires political will because it necessitates capacity-building in individuals, institutions, organizations, communities and societies that may conflict with the interests of the established authority in these groups. Therefore, authorities need to be convinced that socializing of health is not only useful but necessary to tackle the existing challenges of the health system in the Islamic Republic of Iran.

\section{Approaches}

More than 4 decades ago, when the primary health care system of the Islamic Republic of Iran was formed, the main objective was to reduce the substantial burden of communicable diseases and the high maternal and infant mortality rates. As such, the system was designed to treat or reduce diseases. Since then, a better understanding of health and emerging concepts of individual rights has resulted in an increasing demand for disease prevention and health promotion activities among communities. Therefore, a shift toward socializing the health system requires that the current health system approach changes to being health-oriented. In a health-oriented health system, health promotion, disease prevention, and consideration of the deeper causes of ill health (e.g. social determinants of health) are the main priorities compared with the existing goal of the health system in the Islamic Republic of Iran which is to provide therapeutic and curative services.

Involvement in a participatory system requires more complex skills, especially in countries where participation is not widely implemented. Therefore, in order to socialize the health system, there is a need to build capacity for participation and create an enabling environment through a common learning platform, and share health-related up-to-date information, evidence and experiences. The participants expressed this need as, for example: "the social potential must be identified and the people, society and organizations must be empowered," "people should be empowered in primary care" and "individuals, families and communities must be empowered to provide, maintain and promote their health".

This common learning opportunity is also necessary for capacity-building. When resources are limited, the existing capacities of individuals, communities, societies, nongovernmental organizations, and private and nonhealth sectors should be identified and directed towards health improvement, as health is an investment for development.

In developing countries such as the Islamic Republic of Iran, participation and community involvement and engagement are new approaches. Therefore, systematic actions and process-orientated approaches are required to gradually build capacity and enable participation. Participants pointed to systematic action such as: “... so far we haven't had a health system but we have had a health sector, to get a health system, we have to go further and use powers and resources outside the health sector." In addition, they spoke about process orientation: "we must consider that establishing a social health system is a process and happens gradually in a long time span," "we must wait for change" and "socializing the health system is not an easy task. It can take 15 to 20 years. It is important to start and move along." To re-define the norms and values, cultural context and structure to enable participation that justifies a process-oriented approach are needed too.

Health is influenced by social determinants; therefore, a move towards socializing the health system should take account of the social determinants of health. Primary health care together with the social determinants of health should be the focus of a health system that is working towards socialization. Although improving the social determinants of health should not be considered the sole responsibility of the health sector, they cannot be ignored by the health sector.

Health in all policies is a necessary approach for socializing the health system, because the health of people is largely influenced by the decisions made by non-health sectors such as education, employment, agriculture, transport, trade, social services and environment. Health in all policies means that all policies should be made with full consideration of their impact on health.

Figure 2 shows the main values, principles and approaches that should govern socializing of the health system in the Islamic Republic of Iran.

\section{Discussion}

To the best of our knowledge, this is the first study that attempted to provide a conceptual framework for socializing the health system in the Islamic Republic of Iran. Our study provided a consensus on the definition of socializing of the health system and identified its main groups involved. It also defined the core values, principles and approaches of socializing the health system.

Health policies should be guided by values (20), and our study identified participation, human dignity, equity and social justice, ethics, and trust as the main core value of socializing the health system.

Human dignity validates the value of equity and equity is a fundamental ethical basis for all health policies 

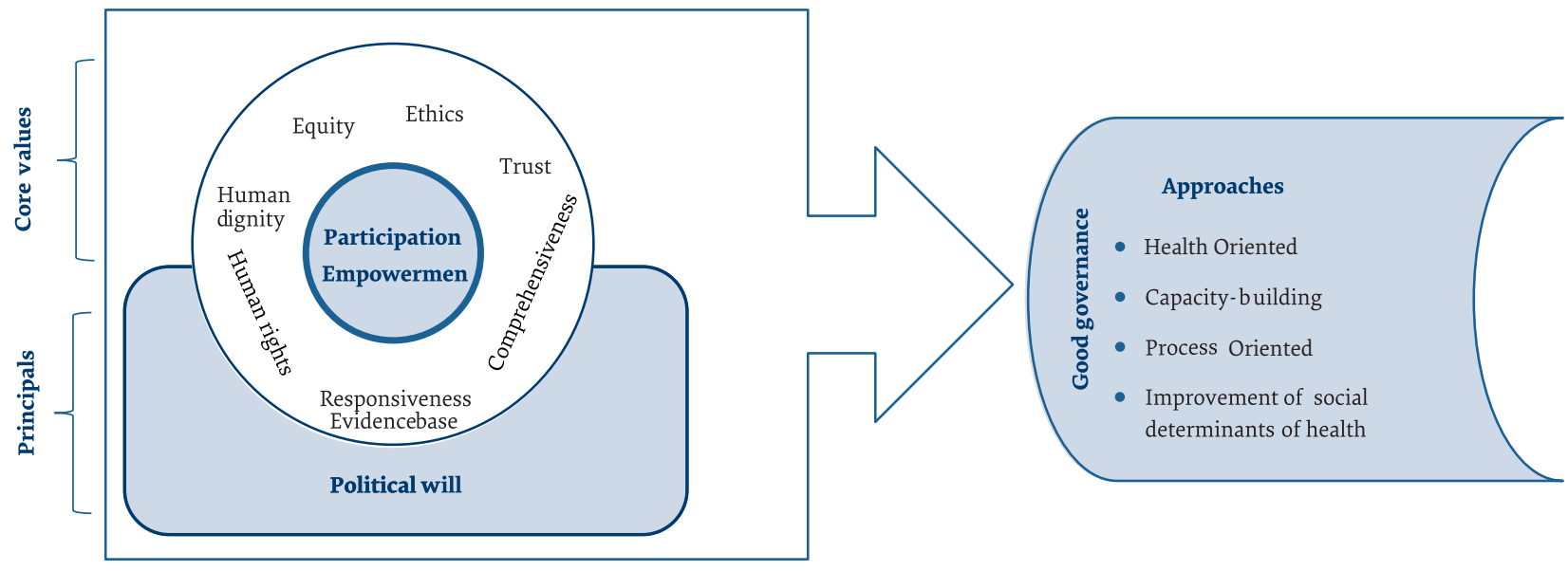

$(21,22)$. WHO identified health equity as the core value for action on social determinants of health, which is based on the principle of human rights (1). Trust was another core value identified for socializing the health system because it enables participation. The health system can enhance the trust of people by increasing the transparency, efficacy, and value for people of their services (23).

Ethics was identified as another core value. It has been said that knowledge and practice of ethics and notions of social justice are prerequisites for those engaged in the health field in the 21st century (24). WHO notes that "equity, solidarity, social justice, reciprocity and trust" are important factors in an ethical approach to public health (20). However, it is also maintained that when there is a conflict between institutional goals and health system goals, or there are competing interests or conflicting values, taking an ethical approach in all policies and activities might be challenging (20). Socializing health could help resolve conflict, making health a common interest and a core universal value.

Our study, not only identified participation as a core value, but also identified the main principles of socializing the health system. The idea of participation has evolved through developmental efforts since 1980 (25). Eight levels of participation have been described and "people control" is the highest level of participation (26). In this paper, there is an emphasis on participation as a process which is characterized by being dynamic, moulded by the participants, responding to local needs and changing circumstance and influenced by bottom-up approaches. Such participation has at its heart confidence and competence, greater individual fulfillment, personal development and self-awareness (27), in other words, the elements of empowerment.

Participation can be promoted by community-based participatory interventions and action-based research or any other innovative approaches that engage people in health preservation and promotion activities $(28,29)$. Health interventions should address the real needs of local communities and should be tailor-made for the particular requirements of a community. The conceptual framework for public health emphasizes this requirement (30), which can be achieved through participation.

Empowerment was identified in our study as another principle of the conceptual framework for socializing the health system. The framework for action on the social determinants of health (1) also identified empowerment as fundamental to people's participation and control of their health. People need to be able to distinguish their real health needs and not to be driven by outside forces that deliver economic benefit or power to a particular group of beneficiaries (31). In addition, empowering minorities and marginalized people through positive discrimination could enable them to participate in improving their health and, in turn, the community could benefit from their abilities and values (32).

Our study identified political will as the main principle of socializing the health system. WHO emphasizes that a high level of politics is necessary for any change in the health system (33).

An orientation on health was one of the approaches selected to promote socializing the health system. This means that the focus of the health system should be on health promotion and well-being, not just control and treatment of diseases.

Our study identified capacity-building as a way to socialize the health system. Capacity-building provides a platform for collaborative learning. This platform also offers an opportunity to conceptualize and consult on health affairs, undertake measures and experience outcomes and then reflect on the data and evidence in a cycle of learning (34-36). The importance of enhancing organizational capacity and improving institutions has also been discussed as necessary to strengthening health systems in low-income countries (37).

The social determinants of health and health in all policies were other approaches identified in our study that should be used to promote socializing the health system. Health in all policies is necessary for health promotion 
across the world (38). One of the responsibilities of the health sector is to create an enabling environment for collaboration with non-health sectors to improve the health of people through enhancing the social determinants of health (4). The slogan "health for all, all for health" emphasizes that the health sector should work to ensure that decision-makers in other sectors take account of health and that they are able to identify the health effects of their decisions and guarantee that not only do they not harm the health of people but they improve health (39).
Our study has some strengths and limitations. Using a mixed-method design to develop the conceptual framework of socializing the health system, which combined in-depth interviews, focus group discussions, panel discussions, review of the literature, and the opinions of a large number of experts within and outside the health sector, increasing the reliability of the information. However, as socializing the health system is a new approach in health system governance, developing a conceptual framework for it needs to be refined and redefined through implementation and evaluation.

Funding: The study was funded by the Social Deputy of Ministry of Health and Medical Education, Islamic Republic of Iran.

Competing interests: None declared.

\section{Cadre conceptuel pour la socialisation du système de santé iranien}

\section{Résumé}

Contexte: La socialisation du système de santé est une nouvelle approche de gouvernance participative qui vise à promouvoir la santé communautaire et à améliorer durablement l'équité en santé dans la communauté. Cette approche fait partie de la réforme du système de santé en République islamique d'Iran.

Objectifs: La présente étude visait à élaborer un cadre conceptuel pour la socialisation du système de santé en République islamique d'Iran en tant que base théorique de cette réforme.

Méthodes : Les données ont été recueillies au moyen d'un examen de la littérature, d'entretiens approfondis, de groupes de discussion thématique et de tables rondes. Les participants étaient des experts du domaine des systèmes de santé au sein du ministère de la Santé et des universités médicales. L'analyse du contenu a été utilisée pour analyser les données et identifier les valeurs, principes et approches clés pour la socialisation du système de santé.

Résultats: Les valeurs fondamentales définies comprenaient la dignité humaine, l'équité, l'éthique et la confiance. Les principes étaient la participation, l'autonomisation, les droits de l'homme, la réactivité et l'exhaustivité. Les approches identifiées étaient la bonne gouvernance, une orientation Favorable à la santé, le renforcement des capacités, une méthode centrée sur les processus et l'amélioration des déterminants sociaux de la santé. Une volonté politique forte est considérée comme essentielle pour la socialisation du système de santé.

Conclusions : Le cadre conceptuel décrit les conditions à remplir pour la socialisation du système de santé iranien. Toutefois, comme il s'agit d'une nouvelle approche de la gouvernance du système de santé, elle doit être affinée et redéfinie par la mise en œuvre et l'évaluation.

$$
\begin{aligned}
& \text { إطار مفاهيمي لتفعيل النظام الصحي الإيراني اجتماعيًّا } \\
& \text { على اصغر فرشاد، روكسانا ميركاظمي، نرجس روستاميجور ان، سيد محمد هادى ايازى، مسعود مطلبي } \\
& \text { الخلاصة }
\end{aligned}
$$

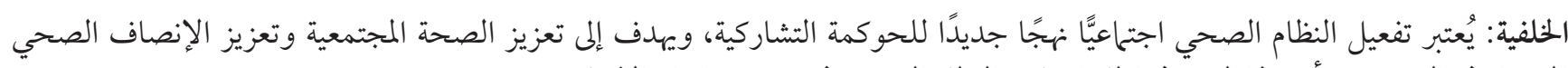

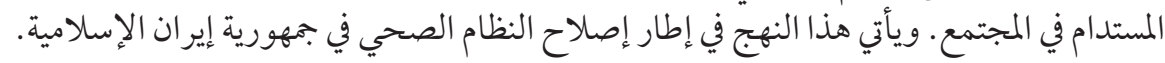

$$
\begin{aligned}
& \text { الأهداف: هدفت هذه الدراسة الى وضع إطار مفاهيمي لتفعيل النظام الصحي اجتماعيًّا في جمهورية إيران الإسلامية، ليكون أساسًا نظريًّا لهذا } \\
& \text { الإصلإح: }
\end{aligned}
$$

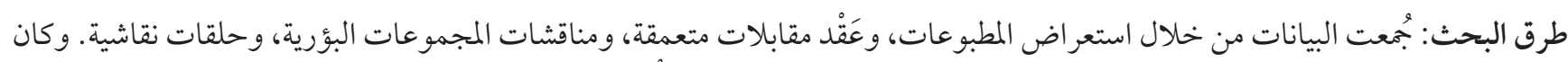

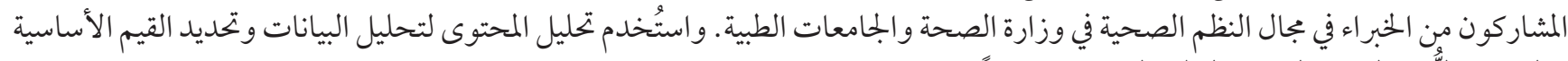

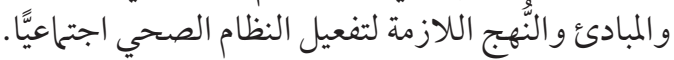




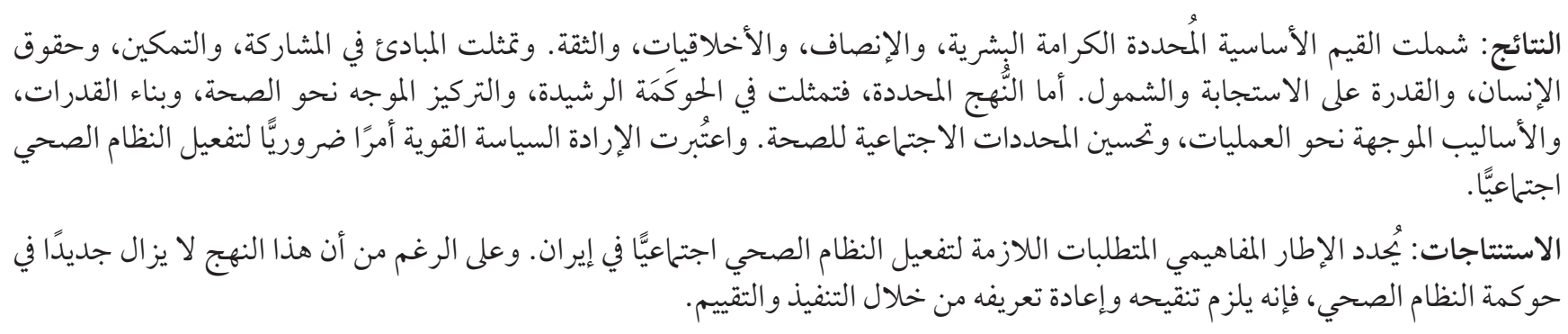

\section{References}

1. Solar O, Irwin A. A conceptual framework for action on the social determinants of health. Geneva: World Health Organization; 2010 (https://www.who.int/sdhconference/resources/ConceptualframeworkforactiononSDH_eng.pdf, accessed 30 January 2021).

2. Baum F, Lawless A, Delany T, Macdougall C, Williams C, Broderick D, et al. Evaluation of health in all policies: concept, theory and application. Health Promot Int. 2014;29(Suppl 1):i130-42. https://doi.org/10.1093/heapro/dau032

3. Leppo K, Ollila E, Peña S, Wismar M, Cook S. Health in all policies. Seizing opportunities, implementing policies. Helsinki: Ministry of Social Affairs and Health; 2013.

4. The Bangkok charter for health promotion in a globalized world. Health Promot Int. 2006;21(Suppl 1):10-4. https://doi. org/10.1093/heapro/dalo46

5. Brinkerhoff DW, Fort C, Stratton S. Good governance and health: assessing progress in Rwanda. Twubakane Decentralization and Health Program Rwanda. Washington, DC: IntraHealth International; 2009 (https://www.intrahealth.org/sites/ihweb/files/ files/media/good-governance-and-healthassessing-progress-in-rwanda/goodgovandhealth.pdf, accessed 30 January 2021).

6. Country cooperation strategy for WHO and Islamic Republic of Iran: 2010-2014. Cairo: World Health Organization, Regional Office for the Eastern Mediterranean; 2010.

7. Heshmati B, Joulaei H. Iran's health-care system in transition. Lancet. 2016;387(10013):29-30. https://doi.org/10.1016/s01406736(15)01297-0

8. Larijani B, Majdzadeh R, Delavari AR, Rajabi F, Khatibzadeh S, Esmailzadeh H, et al. Iran's health innovation and science development plan by 2025. Iranian J Publ Health. 2009;38(1):13-6.

9. Esteghamati A, Meysamie A, Khalilzadeh O, Rashidi A, Haghazali M, Asgari F, et al. Third national surveillance of risk factors of non-communicable diseases (SuRFNCD-2007) in Iran: methods and results on prevalence of diabetes, hypertension, obesity, central obesity, and dyslipidemia. BMC Public Health. 2009;9(1):167. https://doi.org/10.1186/1471-2458-9-167

10. Shahraz S, Forouzanfar MH, Sepanlou SG, BESc PN, Pourmalek F, Lozano R, et al. Population health and burden of disease profile of Iran among 20 countries in the region: from Afghanistan to Qatar and Lebanon. Arch Iran Med. 2014;17(5):336.

11. Rajabi F, Esmailzadeh H, Rostamigooran N, Majdzadeh R, Doshmangir L. Future of health care delivery in Iran, opportunities and threats. Iran J Public Health. 2013;42(Suppl 1):23.

12. Piroozi B, Rashidian A, Moradi G, Takian A, Ghasri H, Ghadimi T. Out-of-pocket and informal payment before and after the health transformation plan in Iran: evidence from hospitals located in Kurdistan, Iran. Int J Health Policy Manag. 2017;6(10):573. https://doi.org/10.15171/IJHPM.2017.16

13. Khodamoradi A, Rashidian A, Aghlmand S, Arab M. Informal payments and its related factors in Urmia hospitals. Hakim Health Sys Res. 2015;17(4):313-21.

14. Aboutorabi A, Ghiasipour M, Rezapour A, Pourreza A, Sarabi Asiabar A, Tanoomand A. Factors affecting the informal payments in public and teaching hospitals. Med J Islam Repub Iran. 2016;30(1):315.

15. Dooris M. Expert voices for change: bridging the silos-towards healthy and sustainable settings for the 21st century. Health Place. 2013;20:39-50. https://doi.org/10.1016/j.healthplace.2012.11.009

16. Nandi A, Welsh L. Social context and mental health over the life course. In: Koenen KC, Rudenstine S, Susser E, Galea S, editors. A life course approach to mental disorders. Oxford: Oxford University Press; 2013:227-38.

17. Marmot M, Allen JJ. Social determinants of health equity. Am J Public Health. 2014;104(4):517-9. https://doi.org/10.2105/ AJPH.2014.302200

18. Ashoorkhani M, Rajabi F, Majdzadeh R. The meaning of "socialization of health" to Iranian policymakers and how it can be implemented. Med J Islam Repub Iran. 2019;33:6. doi: 10.34171/mjiri.33.6

19. Tong A, Sainsbury P, Craig J. Consolidated criteria for reporting qualitative research (COREQ): a 32-item checklist for interviews and focus groups. Int J Qual Health Care. 2007;19(6):349-57 https://doi.org/10.1093/intqhc/mzmo42

20. Global health ethics key issues: global network of WHO collaborating centres for bioethics. Geneva: World Health Organization; 2015 (http://www.who.int/iris/handle/10665/164576, accessed 7 February 2019).

21. Braveman P. What is health equity: and how does a life-course approach take us further toward it? Matern Child Health J. 2014;18(2):366-72. https://doi.org/10.1007/s10995-013-1226-9 
22. Marmot M, Friel S, Bell R, Houweling TA, Taylor S, Commission on Social Determinants of Health. Closing the gap in a generation: health equity through action on the social determinants of health. Lancet. 2008;372(9650):1661-9. https://doi.org/10.1016/ So140-6736(08)61690-6

23. Okello DR, Gilson L. Exploring the influence of trust relationships on motivation in the health sector: a systematic review. Hum Resour Health. 2015;13(1):1-8. https://doi.org/10.1186/s12960-015-0007-5

24. Frenk J, Chen L, Bhutta ZA, Cohen J, Crisp N, Evans T, et al. Profesionales de la salud para el nuevo siglo: transformando la educación para fortalecer los sistemas de salud en un mundo interdependiente [Health professionals for a new century: transforming education to strengthen health systems in an interdependent world.] Rev Peru Med Exp Salud Publica. 2011 Jun;28(2):337-41. https://doi.org/10.1590/s1726-46342011000200023

25. Hickey S, Mohan G, editors. Participation - from tyranny to transformation: exploring new approaches to participation in development. London: Zed books; 2004.

26. Arnstein SR. A ladder of citizen participation. J Am Inst Plann. 1969;35(4):216-24. https://doi.org/10.1080/01944366908977225

27. Toomey AH. Empowerment and disempowerment in community development practice: eight roles practitioners play. Community Dev J. 2011;46(2):181-95. https://doi.org/10.1093/cdj/bspo6o

28. Davoudi S. Planning as practice of knowing. Plan Theory. 2015;14(3):316-31. https://doi.org/10.1177/1473095215575919

29. Practitioner's guide: rights-based approach to participation. Geneva: Global Initiative for Economic, Social and Cultural Rights (GI-ESCR); 2014 (https://www.escr-net.org/resources/practitioners-guide-rights-based-approach-participation, accessed 30 January 2021).

30. Abdi Z, Majdzadeh R, Ahmadnezhad E. Developing a framework for the monitoring and evaluation of the Health Transformation Plan in the Islamic Republic of Iran: lessons learned. East Mediterr Health J. 2019;25(6):394-405. https://doi.org/10.26719/ emhj.18.067

31. Wallerstein NB, Yen IH, Syme SL. Integration of social epidemiology and community-engaged interventions to improve health equity. Am J Public Health. 2011;101(5):822-30. https://doi.org/10.2105/AJPH.2008.140988

32. Gürtler M, Gürtler O. Promotion signaling, discrimination, and positive discrimination policies. Rand J Econ. 2019;50(4):1004-27. https://doi.org/10.1086/662072

33. WHO Regional Committee for the Eastern Mediterranean resolution EM/RC50/R.12. Primary health care: 25 years after Alma-Ata. Cairo: World Health Organization, Regional Office for the Eastern Mediterranean; 2003 (https://apps.who.int/iris/bitstream/handle/10665/122206/em_rc50_r12_en.pdf?sequence=1\&isAllowed=y, accessed 7 February 2019).

34. Kolb AY, Kolb DA. Experiential learning theory: a dynamic, holistic approach to management learning, education and development. In: Armstrong S, Fukami CV, editors. The SAGE Handbook of Management Learning, Education and Development. London: SAGE Publications Ltd; 2009:42-68. https://doi.org/10.4135/9780857021038.n3

35. Rashidian A, Mandil A, Mahjour J. Improving evidence informed policy-making for health in the Eastern Mediterranean Region. East Mediterr Health J. 2017;23(12):793-4. https://doi.org/10.26719/2017.23.12.793

36. Roth MG, Rubin JC, Omollo K, Friedman CP, Seagull FJ. The learning health-system: a new frontier for human factors. Proc Int Symp Hum Factors Ergon Healthc. 2016;5(1):141-4. https://doi.org/10.1177/2327857916051020

37. Swanson RC, Atun R, Best A, Betigeri A, de Campos F, Chunharas S, et al. Strengthening health systems in low-income countries by enhancing organizational capacities and improving institutions. Global Health. 2015;11(1):5. https://doi.org/10.1186/s12992-0150090-3

38. Peña S. Health in all policies. Paper presented at the 8th Global Conference on Health Promotion, Helsinki, 9-14 June, 2013.

39. Health in all policies: Helsinki statement. Framework for country action. Geneva: World Health Organization; 2014 (https://apps. who.int/iris/bitstream/handle/10665/112636/9789241506908_eng.pdf?sequence=1, accessed 30 January 2021). 